\title{
After Madoff: Waiting for Justice
}

\author{
Lionel S. Lewis
}

Published online: 27 January 2011

(C) Springer Science+Business Media, LLC 2011

This essay examines how Madoff's victims adapted to their suddenly diminished financial security, status, and self image after learning that they had been swindled. The primary foci are: (1) What they were thinking and feeling about their changed circumstances and (2) How they were coping with them. To best answer these and other questions, during the summer of 2010 - approximately a year after Madoff was incarcerated-letters and e-mails were sent to all but seven of the initial list of 167 victims asking for up-to-date descriptions of family, financial, and health challenges they had encountered, had overcome, and were still facing. Some victims, when it seemed appropriate, also were asked to comment on the activities of other victims whom they knew, had read about, or in other ways had heard about since Madoff was arrested.

Forty-two individuals or couples responded favorably to the request to participate in this phase of the study, and an additional eight responded but declined to provide additional information beyond what had already been gathered. Moreover, 14 of the 42 were interviewed, seven one time, four twice, and three thrice. Thirteen of the 167, along with 16 other individuals, contributed a brief memoir to a volume of essays, letters, and poems put together in 2010 by a group of Madoff victims and family members, and what the thirteen wrote was utilized to supplement information previously provided by them or otherwise collected for their files. As an interpretive framework, Erving Goffman's observations about the social processes that come into play for placating those who have suffered a

L. S. Lewis $(\varangle)$

17 Morningside Lane,

Williamsville, NY 14221, USA

e-mail: socls1@buffalo.edu loss, who have been cheated or who may feel cheated or in other ways disappointed, are used.

\section{"On Cooling the Mark Out"}

In one of his highly original essays, "On Cooling the Mark Out," Erving Goffman first turns his attention to crime and its victims, particularly those taken in by a "confidence man" (or woman or gang) and by their need to adjust to their loss - to the realization that they had actually been deceived and cheated. Of particular relevance, Goffman notes that "the con [the swindle] differs from politer forms of financial deceit in important ways. The con is practiced on private persons by talented actors who methodically and regularly build up informal social relationships just for the purpose of abusing them; white-collar crime is practiced on organizations by persons who learn to abuse positions of trust which they once filled faithfully. The one exploits poise; the other position." It is immediately apparent why Goffman's insights prove especially valuable in framing and understanding the information provided by Madoff's victims about what they thought, felt, and did in the aftermath of experiencing their loss and disappointment.

Since loss and disappointment are part of the human condition, the true significance of Goffman's essay is, of course, that the themes he explores go far beyond those who have been cheated in a confidence game. His insights help further our understanding of those who have a grievance about any loss and disappointment. This would include those victimized because of their actions or because of the actions of others who also may have been taken in.

Goffman contends that the con is "a good racket in the United States only because most Americans are willing, nay eager, to make easy money, and will engage in action that is 
less than legal in order to do so. The typical play has typical phases. The potential sucker is first spotted and one member...arranges to make social contact with him. The confidence of the mark is won, and he is given an opportunity to invest his money in a gambling venture which he understands to be fixed in his favor. The venture, of course, is fixed, but not in his favor. The mark is permitted to win some money and then persuaded to invest more. There is an 'accident' or 'mistake' and the mark losses his total investment." The Robert Redford-Paul Newman movie The Sting (inspired by real-life events) with all of these elements - the quest for easy money, the bait with the promise of a sure win, the ruse to gain trust, and the loss of everything due to a misunderstandingportrays perfectly how a con works. Madoff's Ponzi scheme, since it began sometime after the 1973 release of The Sting, might be looked at as life imitating art. Although as inventive, complex, and typical, it proved far less entertaining.

Goffman also notes that sometimes a mark is not prepared to accept a loss, and may feel moved to complain to authorities. In order to avoid such adverse publicity, an additional phase "is sometimes added at the end of the play. It is called cooling the mark out."

Although the reaction of anyone who has been swindled is unpredictable, con men depend on their "grift sense" to tell them roughly what an individual's reaction will be. Will he cry or complain? Will she do something ridiculous? Maurer has written that "some marks are tough and can cause plenty of trouble if they get out of hand. Some are well-bred and take their medicine like men. Laughing marks are usually considered the most dangerous.... Some marks are mean, grasping, and cunning." "It is easy for the layman to understand," Maurer adds, "why some marks blow up when they realize that they have been trimmed [cheated]. If these marks are not properly cooled out, they may get the mob into serious trouble...." At the same time, "many of them [marks], realizing or suspecting that they have been swindled, immediately cause trouble, and all the ingenuity and persuasiveness of the inside man is required to prevent serious repercussions; sometimes all that fails and the con men are indicted. But not very often, considering the large number of marks who are beaten." To minimize repercussions, it is obviously worthwhile to make an effort to cool the mark out.

However, besides the short court trial, where a handful of victims were briefly permitted to crush Madoff verbally and to listen to the sentencing judge do the same, this element was missing in the months following his arrest, when his victims were most unsettled. There was little to keep the anger of Madoff's victims, the marks, "within manageable and sensible proportions." In short, there was insufficient consolation and very obviously this exacerbated an already unacceptable situation. It would not have surprised Goffman that very few of Madoff's victims were willing to accept their loss. Almost immediately, a number were busy challenging individuals and institutions which they believed were not sufficiently engaged in working on their behalf to overturn the damage caused by Madoff, and which fell short of adopting their world-view. As time passed, more joined their efforts. The majority who became active in pressing their case stayed active; in the first year the involvement of only a few flagged.

From the beginning, the victims' situation was untenable given that a number of those who had invested with Madoff were convinced that: (1) They were privy to inside information (Hadn't a bridge partner or someone in their golf foursome told them their investment was a sure thing?); (2) They were entitled-a view that the successful careers of so many of them made plausible and readily acceptable; (3) They were smart, a belief so many middle class American hold about themselves; (4) They could not lose (after all, their cousin's niece was building quite a nest egg with Madoff, and she was not yet 40 years old.); (5) They were deserving. In fact, an incredibly large number described themselves as "frugal" and "hard-working," an assessment sometimes, but not always, borne out by their biographies:

We lived simply, in an apartment while putting money aside to purchase a future home. Since I was not an earner, I contributed by taking on responsibilities that would have cost money. So I did all the housework, cleaning and polishing, washing and ironing, hemming and altering plus I gave up personal expenses like beauty parlors and bought only inexpensive clothing. We drove used cars, camping was the way we vacationed. I set up a tiny section of our bedroom for a studio and snatched little bits of time to paint.

Also my sense of community responsibility, inherited from my parents, was always with me. School issues became a major concern and soon I became president of a very large, active PTA. I called a conference where we determined the books in elementary schools did not reflect the diversity of our city. As a result the books were rewritten. And we achieved that goal. That was just one of the many worthy projects to which I gave time. (Client \#28)

We didn't live with millions of dollars. We lived with people like ourselves-middle class people who worked damned hard to earn a buck. (Client \#123C)

It is hardly surprising that some dropped their usual defenses which had heretofore protected them and their families from being victimized in matters small and large. As a result, all lost a significant amount of their savings; a 
number reported they were left penniless or, as they saw it, nearly penniless. On top of this, they had no protection from media-fueled second guessing and ridicule from friends, acquaintances, and strangers. A few, but only a few, began to see what those who had not suffered a loss at the hands of Madoff saw, namely, that perhaps they were not as shrewd or smart as they had thought, but simply marks in a very large, long-running, and, for them, invisible con game. The situation was continually made much worse by the probing media, or from media which mindlessly echoed their self serving and sometimes erroneous claims while drowning out voices that might otherwise have helped cool them out. In fact, a small number seemed to be vying to see how often they could be interviewed by a television or newspaper reporter. (See Appendix for an example of a joint television interview of nine victims, seven of whom were from the initial list of 167, covering myriad issues.) They did not have, as they had convinced themselves, an inside track on safely and profitably investing. Some, if not all, self images surely suffered. The absolute necessity that they be consoled, that they be "cooled out," was immediately evident, but it rarely happened.

After the swindle in The Sting, the mark is quickly hustled out of the fake betting parlor by a police officer, being told that it is better to lose a substantial amount of money than to become fodder to the press or even to become implicated in a double homicide. However, for Madoff's victims there was no social mechanism, no representative of the law or government to perform this function. Some government agency might have done so, but none did. On the contrary, the staff of the SEC, which may have served this function, had with each passing week revealed how hapless and dysfunctional it had become. Moreover, the trustee who represented Madoff's estate and the SIPC made a number of decisions with which most victims vehemently disagreed. On top of that, the courts supported the trustee's interpretation of the law and his actions. Finally, the government sometimes seemed to go out of its way to wrong victims. Client \#23 reports, for example: "We filed a claim with the IRS for a refund due to a theft loss and received a refund of $\$ 30,000$ for a 5 -year period which was great, but then they decided to audit us for the theft loss and said they want the money back until they can determine if the Madoff claims are truly a theft loss.... So we are working that out now.... The IRS believes that the money still exists (per our IRS agent information) and given that they are contesting most of the refund claims, we are told."

Goffman reminds us that it is a mistake in a con game to account for the greatness of anger by the greatness of financial loss: "In many cases, especially in America, the mark's image of himself is built up on the belief that he is a pretty shrewd person when it comes to making deals and that he is not the sort of person who is taken in by anything. The mark's readiness to participate in a sure thing is based on more than avarice; it is based on a feeling that he will now be able to prove to himself that he is the kind of person who can 'turn a fast buck'." At best, their loss and disappointment only proved to Madoff's victims that they were no wiser than they were decades earlier, that they had not been taught or learned a great deal over the years. "Why should I suffer any loss?" Client \#31A asked. "It might not seem like a lot, and I can earn it all and more back in less than 2 years, but it was mine and not Madoff's to buy another house with." Client \#86 concurred: "It's not the money, which is no big thing, but the principal (sic). It [the loss] isn't going to make us change how and where we live, but I still intend to get every dollar back no matter how long it takes."

It is hardly surprising that not only were there few if any victims of Madoff who would share Goffman's (or a career con man like "Yellow Kid" Weil's) conclusion that some of them might have been a little too eager to make money and that was why in the end they lost it. Instead, many victims became infuriated at even the suggestion that they may have done anything which had contributed to their financial losses. When it was suggested to Client \#97B that the victims not only did not want to take any responsibility for their financial losses, but believed in their complete innocence, he indignantly wrote: "You are completely clueless as to why we feel the way we do, and in many cases your description of the victims is so completely wrong and demonstrates your ignorance and misperceptions of the history of Madoff." He, not unexpectedly, refused to participate further in the study.

Actually, there were many as deeply hurt and suspicious after the loss of all or a large percentage of their economic security. (Client \#97B, whose investment in the Ponzi scheme was largely from his professional earnings, "lost $\$ 3$ million to Madoff.") After such a searing experience, it is surprising that any were willing to participate in the study or be interviewed, although one journalist reported that "once word got out that I was going to write an article about the Madoff mess, my cell phone never stopped ringing. Victims I hardly knew wanted to tell their stories, vent their anger, get revenge."

\section{Challenging the SIPC}

Even in light of the many bruised egos and small amount of help from government sources, the degree of suspicion about the motives of the public face of the federal government, the SIPC and the trustee, seemed excessive. In the expression of anger here nothing was out of bounds. 
In spite of the amount of time they spent, the economic and psychological costs incurred, and the complete lack of success in their efforts, the victims assaulted the trustee at every turn.

The crux of the feud with the SIPC and the trustee was a disagreement about the meaning and interpretation of the Securities Investor Protection Act (SIPA) of 1970 (and its 1978 amendments). First, Madoff's victims believed that they had insurance against losses. However, a court decision in 1975 ruled that the SIPC is not an insurer, nor does it guarantee that customers will recover their investments which may have diminished as a result of, among other things, market fluctuations or broker-dealer fraud. This was the trustee's position. Second, most of Madoff's victims - those who invested directly with him and those who invested indirectly with him through a feeder fundheld that they were entitled to SIPC benefits. However, court decisions have held that Congress intended SIPA to protect only those who entrusted property directly to a broker, specifically. The only type of investor who qualified as a customer of a broker-dealer was an investor who paid cash directly to a broker-dealer. Indeed, one court decision pushes this definition further, stating that individuals who unwittingly invested in a Ponzi scheme by issuing checks payable to anyone other than to the failed broker, were not customers within the meaning of the SIPA. This was the trustee's position. In a court filing, the SIPC held that to be truly a Madoff customer, an investor must have had a securities account with him or had cash or securities with him with the reasonable expectation that an account would be set up, and must have entrusted cash or securities for the purpose of investing in securities. This could only be "ascertainable from the books and records" of Madoff.

Third, Madoff's victims argued that their net equity was what they had invested with him. However, the courts interpreted net equity to mean total value of cash and securities "less total value of cash and securities" the customer owed to the broker. Thus, according to the courts, net equity can be easily determined by calculating what would have been owed the customer if securities had been liquidated. The reasoning was that because for Madoff's victims there were no securities to be liquidated, accounts were valued according to what was invested minus what was withdrawn. This was the trustee's position. Fourth, some Madoff victims believed they were entitled to interest on their investments. However, the courts ruled that the SIPA does not authorize the payment of interest on customer accounts. In fact, when a brokerage firm was operating a Ponzi scheme this did not include supposed interest that customers were to receive on their investments; rather, customers were entitled, subject to statutory limits, to only the return of their principal as reduced by any amount which they had received from brokerage, whether as interest, return of principal, or any other payment. This was the trustee's position.

Fifth - and what was surely the most contentious issue as far as the victims were concerned-was how the total amount of their investment should be determined. A large majority of the victims (at least those who expressed their view on the matter) believed that the value of their account could be found in the November 2008 statement from Madoff, the last one they received before his arrest. Yet, this was contrary to a 2004 court case, which held that claims of purchasers of bogus securities were required to be valued at the amount they initially paid for them, and could not include any artificial interest or dividend reinvestments reflected in fictitious account statements that may have been received. This was the trustee's position.

A number of victims who were not initially convinced that they had been wronged by the government's take on one or more of these points of disagreement were shortly convinced otherwise by other victims - often by means of online websites (online communities, online networks, online social support groups), which mushroomed and thrived. Attorneys also were instrumental in persuading victims that the most effective way of forcing the trustee to reverse a position, that is, of "getting the complete justice they deserved," was going on the attack not only against the trustee, but also his staff, and the SIPC. Among other things, they initiated lawsuits, complained to their elected representatives and the media, and wrote e-mails and letters. Victims also were urged to challenge the courts, which interpreted the law in the same way as the trustee. This was not an easy matter; yet they persisted. In their dispute with the trustee, the victims often spoke about fairness, principles, equity, justice, and the like. But it was quite evident that they were less moved by these concepts than by the wish to get as much of their investments returned to them as possible, and they expected-some demanded - prompt action. At bottom, many disputes were about money and little else: "I think the way we have been treated by everyone shows that most people today lack compassion.... I would think," Client \#72 argued, "everyone would agree that as a country we would all be better off if more of us practiced the 'Golden Rule'.... That's really what this country is about.... Yes, Congress and the president should see that we get all of our money back plus interest." And again: "Does anyone not agree that we have been hurt by unfair treatment? And why is it that only those who play by the rules end up being hurt? ... I would hope that you would understand that if fair play wins out, our IRA and the IRAs of others will be fully restored.... Who wouldn't want [their] money back?"

The SIPA and the courts had given the trustee broad and nearly unassailable power, and it was clear it would not be easy to convince him to return any more to the victims than 
he believed the law, as he interpreted it, said they had coming. He was unyielding, and not much interested in what he saw as peripheral issues. His firmness only incensed victims, who believed that he was unnecessarily unyielding. They were convinced that the questions they were raising were truly relevant and worth considering. They felt he too often ignored them.

Not everyone, of course, was disappointed at the government's response to their plight. When, for example, one of the nine individuals (Client \#86) selected to denounce Madoff at his sentencing trial in June received his $\$ 500,000$ check from the SIPC four months after he had submitted his claim, he was elated. Although Madoff had stolen \$5 million from him and the government payment was only $10 \%$ of that amount, he understood that by law it was the maximum the government would reimburse any account and he considered himself "well off by any reasonable standard and for that I am grateful." The money would be of immediate use to pay off the first mortgage on his home. He seemed particularly pleased that he was among the first claimants the SIPC paid. (A few other victims groused that his claim was readily settled because he had political connections. This unsubstantiated accusation found its way into the media.) He promptly returned his questionnaire and optimistically wrote: "Since I lost almost $\$ 5,000,000$ by investing directly with Madoff and indirectly through two feeder funds and because the overall economy has experienced an extremely severe recession, naturally my financial situation has deteriorated. I still consider myself well off financially and certainly have no reason to complain when so many millions of people cannot find jobs.... I immediately [as he had averred he would] paid off the mortgage on our home. We also received considerable tax refunds from the federal government, but not from [the state in which he resides], which refuses to refund the taxes we paid on fictitious income." It is noteworthy that at the time he received the $\$ 500,000$ from the SIPC, 99 percent of the nearly 9,000 Madoff investor claims at that point had not even been approved. Nonetheless, few of Madoff's victims would be as pleased by the SIPC's action.

And Client \#101 understood that her "situation [was] probably a little different from" that of most of Madoff's victims. She was younger than most and had two young children. A few months before Madoff was arrested, she was diagnosed with thyroid cancer and had a thyroidectomy, and after that she discovered that her husband was having an affair with her best friend. Still, after "losing all my money" she found employment and with the help from other friends and relatives, but none from the government, she reported that her "life is much better now than it was before the Madoff fiasco actually." She concluded that she got "pleasure from [her] work..., [and that] I'm actually a very lucky person."

Both Clients \#86 and 101 were clearly part of a tiny minority.
More typically, an individual who had written a succinct and compelling victim impact statement (Client \#143) promptly became the co-principal in a lawsuit against the trustee, claiming that he had treated her unfairly in adjudicating her claim. After an unfavorable court decision, she brought another action, but again she was unsuccessful. Her attorney, who herself had invested with Madoff, did not cool her out. On the contrary, she urged her not to back down, to continue to seek redress in the courts. The attorney, in fact, had written the court earlier demanding that victims "must be given a seat at the table. To date, we have not been given that opportunity...in the bankruptcy proceedings...." She went on to remind the court that "people in their 90's are being put into nursing homes for the first time in their lives because their children can no longer afford to maintain them in private homes. People in their 70's and 80's, who retired with the assurance of a steady income from their Madoff accounts, are being forced to sell their houses in a depressed market in order to have money to buy food...." She asked that the government become more active in finding the stolen funds, and that the court "appoint a committee of investors [to help] assure restitution to Madoff's victims." Given the rawness of the attorney's emotions, it is hardly surprising that this client and any of her other clients were not prepared to accept their losses. Whatever the challenge, the trustee remained unmoved, and was certainly not prepared, himself, to cool victims out.

Three irreversible decisions by the trustee, the SIPC, and its attorneys were centermost to this and to other victims' bitterness. First, the trustee and the SIPC would not budge from the decision to pay its full $\$ 500,000$ insurance obligation only on the amount investors actually invested with Madoff, less any withdrawals they may have made (that is, net investment), ignoring years of phantom profits on which taxes had been paid. The SIPC did not see the tax issue of some victims as a problem it needed to solve. Second, the trustee was determined to recover the money that investors may have withdrawn from their accounts that was in excess of their investment with Madoff. He had set in motion a plan to promptly move ahead on this matter. This was called a "clawback." Third, he continued to insist that only funds directly invested with Madoff, and not those invested in feeder funds, were covered by SIPC.

According to the aforementioned lawyer's 2009 congressional testimony - and math - at about the time she was writing the court, these procedures established by the SIPC "would reduce the total Madoff claims from $\$ 64.8$ billion to approximately $\$ 21$ billion and...reduce the number of customers entitled to SIPC insurance from approximately 4,904 account holders to 2,335 account holders." She also contended that the SIPC proposal that individuals "pay back to the bankruptcy estate all funds withdrawn within 
the past 6 years up to the amount of the negative net investment" was grossly unfair.

What she and some of her clients actually wanted was to replace the trustee after he had denied "prompt replacement of up to $\$ 500,000$ of ... securities as reflected on their November 30, 2008 statement received from Madoff." They were convinced that getting the court to remove the trustee was a first and necessary step that needed to be taken if they were to have any success in their efforts to be made financially whole. The trustee and the SIPC had argued in court that returning the amount clients found in their November 2008 statements was completely "impracticable," as the statements reflected non-existent investments and were, of course, complete fabrications. Much to the annoyance of Madoff's victims, the attorney for the SIPC told the judge that "no one in their right mind" would use financial statements that were simply fabricated by Madoff as a basis for calculating assets: "The last customer statement, being a concoction of a fraudster, is not something on which you can rely" in calculating net equity. (When victims later learned that in just one four-month period this attorney submitted a bill to the court for $\$ 837,457.50$, having worked $1,015.10$ hours at $\$ 825$ an hour, they could only be described as absolutely rabid.)

The SIPC held firm that of the 15,870 claims that had been filed at that point only 2,336 were truly valid, as they were the only ones that had a net loss. This also further infuriated a number of Madoff's victims. The SIPC was holding fast to the trustee's method for compensating investors: "cash in/cash out." In effect, with this decision, the trustee had reduced the SIPC's liabilities from more than $\$ 7$ billion (certainly not $\$ 64.8$ billion) to approximately $\$ 1.2$ billion. (All of these numbers were constantly changing, and will continue to change before all matters are fully resolved over the years. At a later date, with more than 15,000 claims filed, the Madoff trustee Website valued the total number of "allowed claims" at roughly $\$ 5.2$ billion.) The condescension and firmness on all matters by the SIPC legal team completely enraged the Madoff victims, who repeatedly challenged the trustee but with no success. They were prepared for a long and bitter fight, and this is exactly what they were in the midst of.

The bankruptcy judge, although expressing sympathy for the defrauded investors, concurred with the SIPC trustee, writing "the account statements are entirely fictitious, do not reflect actual securities positions that could be liquidated, and therefore cannot be relied upon to determine net equity." He concluded that because securities were never "ordered, paid for, or acquired...the only verifiable amounts that are manifest from the books and records are the cash deposits and withdrawals."

The Madoff victims were not deterred. For her part, the attorney for the Madoff investors argued that the trustee's actions were "solely to enrich SIPC at the expense of SIPC's insureds." She expressed the seemingly overlarge concern that "aside from the devastation Picard [the trustee] has caused to thousands of customers, he has created a serious threat to the national economy because he is single-handedly destroying investor confidence in the capital markets." She was one of the first to suggest that at bottom the trustee was more interested in saving the SIPC money than in helping the victims recover their money. He was more concerned with minimizing the losses of brokers and bankers than those of investors. One victim referred to him as a "stooge." Another victim described him as a "thief," and "no better than a hired assassin." Another victim called him a "pimp." Another victim simply wondered why he was so calloused, so determined to use them as "pawns." As this very much involved lawyer saw it, what the trustee had done was much more than unlawful; it was a "violation of the public trust." In fact, however, the public was becoming less sure of this assessment. To the decreasing number of the public still paying attention, the tactics of the victims were beginning to look "desperate" and "greedy." (Although his victims had largely lost interest in Madoff after he was found guilty and imprisoned, the public, fascinated by the grandness of his Ponzi scheme, was still very much interested in every detail of his life in prison fed to them by the media. Like Princess Diana, O.J. Simpson, Natalee Holloway, or Nelson Mandela, Madoff had become a bona fide celebrity.)

In the eyes of many of Madoff's investors, the effect of the totality of the SIPC's decisions was to victimize them yet once again. This became an idée fixe.

\section{The Trustee}

Very quickly, and not surprisingly, the trustee became the primary target of the victims' considerable and continually growing anger. His actions had done little to cool them out. At the same time, the trustee soon became the only face of the government. The widespread view in government circles was that those whose money had been stolen by Madoff were surely unfortunate, but not deserving of extraordinary help, not deserving of a government rescue, or, as some elected representatives and those in the media put it, "a bailout." The trustee apparently also held this view. As they continued to question and pummel the trustee on every point, as they continued to press their case, the victims came to be seen more and more by outsiders as simply greedy. The reservoir of sympathy for them had begun to evaporate more and more rapidly.

At this point, at least publicly, the trustee appeared to be very much concerned about the plight of the victims, yet there was absolutely no hope of his adopting any points they were so keen in making, let alone their world-view. As he saw it, his responsibility was straightforward: His job 
was to collect as many of the assets that Madoff had not spent or that had not inexplicably vanished and distribute them fairly to those whose money had been lost in the Ponzi scheme. He continued to argue that his "cash in/cash out approach to calculating 'net equity' is the only one consistent with SIPA [law], bankruptcy law, principles of equity, and common sense."

The trustee was aware that there would be many challenges to the method being used to determine claims. In fact, by March 31, 2010, over 2,600 objections had been filed with the Bankruptcy Court. Some victims continued to insist that the cash in/cash out approach was arbitrary and unfair, that the value of a claim should be based on their November 30, 2008 statement; some still wanted interest paid on their investment; some believed that they were entitled to an immediate payment of $\$ 500,000$; some argued that indirect investors, not only direct investors, should be covered by the SIPC; some contended that each name on a joint account should be eligible for an SIPC payment. The trustee was besieged on all sides. Not once did he waver.

Regardless of their lack of success in court against the trustee, some victims were undeterred in their efforts to thwart his efforts to move ahead. At times the court grew impatient with their unwillingness to accept the fact that they had been swindled, and to quit contesting each step in the process of collecting and redistributing what Madoff had accumulated. When, for example, after losing a decision, a plaintiff filed again, "raising virtually the identical issues," the exasperated judge concluded that the entire exercise was "bordering on [the] frivolous." The trustee found most allegations against him to be "spurious," but was decidedly bothered by the fierce ad hominem attacks against him and the SIPC staff. He seemed truly surprised by how many were suspicious of every action he took. By tying him up in legal minutiae, the victims were slowing his work of cleaning up the mess Madoff had left behind. Of course, the longer he was required to stay on the job, the more he earned as trustee. What he was doing may at times have hurt him personally, but it was surely lucrative, thanks in part to the victims' activism.

At times, Madoff's victims were uncharacteristically quiet when the trustee resolved a complicated matter. They were silent, for example, when in late August 2010 he convinced the judge overseeing Madoff's business affairs to ask the Supreme Court of Gibraltar to transfer \$73.1 million to him to use to compensate those who had lost money in Madoff's Ponzi scheme.

\section{And Suing the Trustee}

On the other hand, about a week after this trustee success, a number of victims joined two lawsuits challenging a nearly
\$34 million bill for work the trustee and his firm had performed in the previous quarter, from February 1, 2010 through May 31, 2010. In the first suit, the plaintiffs reminded the court that "this equates to $\$ 5,010$ in daily compensation, including all weekends and holidays, for the trustee, and $\$ 283,179.45$ in daily compensation for [his law firm], again including all weekends and holidays.... These figures are excessive by any measure and should not be approved...." The core of one suit was that "investors have no ability to evaluate the efficiency or professionalism of the work" because "detailed billing reports" were not filed. The contention was that these eye-popping fees "come directly from SIPC - from the very money that is necessary to pay investors the $\$ 500,000$ in SIPC insurance to which they are entitled under SIPA."

The second suit alleged that "the trustee has failed to disclose material information," information "vital for customers to know and yet it has been concealed from customers and the public"; and that "the trustee and [his law firm] have a conflict of interest" in that the trustee and his law firm "are far from "disinterested": as a result of which "they are barred from receiving any compensation under established precedents and principles of professional conduct."

In a 47-page response, the attorney for the trustee not unexpectedly restated that "the trustee and his counsel continued to work diligently on behalf of customers" and Madoff's estate. He also repeated that "no administrative costs...will be paid out of any recoveries obtained by the trustee for the benefit" of Madoff's clients. The filing also summarized the trustee's professional background and services. The trustee was still proceeding very deliberately. (As of August 13, 2010, the trustee had determined 13,286 customer claims, of which 2,188 were allowed, and had committed to pay approximately $\$ 715$ million in funds advanced to him by the SIPC. The allowed claims totaled over $\$ 5.5$ billion.)

Only weeks earlier the trustee had issued a report detailing his activities, and here he was compelled again to make the case that his efforts were unflagging. He attempted to quiet his critics by pointing out that he had gathered and organized approximately seven thousand boxes of paper documents, identified approximately 8.3 million pages of documents to scan, was working to assess the contents of more than 4,000 reels of microfilm and 87 transfile boxes of microfiche. He had also accumulated and stored 1.4 million e-mails. Yet at this point, his staff was still able to review 12,249 claims, of which 2,011 were allowed for a total of $\$ 5.3$ billion, and he had committed to pay $\$ 668$ million in cash advances from the SIPC. For the most part, he denied the other 10,238 claims either because those accounts had withdrawn more money than had been deposited or the claim was filed by someone who was not a 
direct investor with Madoff. At the same time, the trustee had recovered $\$ 1.5$ billion and had filed fourteen avoidance actions seeking to recover more than $\$ 14.8$ billion in principal and fictitious profits from various feeder funds, Madoff family members and friends, and related parties. He had also issued subpoenas to more than 600 parties and received approximately 6 million documents. If nothing else, his office was extremely busy, and was kept busier by the constant assaults on it by Madoff's victims. Victims held him up with legal maneuvers, and then wondered why his work did not progress more rapidly and why it had become so costly. Nearly 16 months after Madoff's arrest, only 1,769 accounts out of 16,314 claims had been fully or partially satisfied. Of the claims, 4,273 were under review and 7,865 were denied, for which no objections were filed. These figures were at the core of the agitation of many of Madoff's victims and their supporters, family, friends, attorneys, and journalists who had a public forum:

The Securities Investor Protection Corp., (SIPC) whose logo brokerage firms pay to print on their statements to gin up a sense of security among retail customers, has not paid back the bulk of Madoff investors, although the agency was set up under the Nixon administration for the express purpose of protecting Americans who tangle with Wall Street. In a strangely twisted view, SIPC is actually proud to have not helped investors who are victims of Wall Street fraud, including Madoff investors. Is the SIPC logo on your brokerage statement? Probably. Don’t expect any money back, even when it's been stolen from you outright.

A number of victims joined in the outcry. Client \#97A confessed to being overwhelmed by "rage against [the] injustice" she confronted at the hands of SIPC:

None of the victims are "winners." We are all losers. The only winners in the debacle are [the trustee] and his law firm who have been making over a million dollars a week for over a year now. To imply that any of us are winners is disgusting.... We feel it's immoral to again victimize people who lost their life savings by demanding back money they withdrew in good faith and which they believed was theirs. Elderly people are being tortured by the threat of clawbacks, fearing the little they have left and their homes will be taken from them.

Mr. Madoff isn't deciding who is entitled to restitution. Mr. Picard [the trustee] and Mr. Harbeck [also from SIPC] are. They have used that absurd statement to deflect attention from their failure to adhere to SIPA legislation. They are not working for the victims. Their goal is to limit SIPC's financial exposure and hence that of the securities industry. They claim that by using their calculations more victims will be helped. This is simply not true....

Their claim that SIPC is not insurance is a smoke screen. SIPC...might not have the word "insurance" in its name as FDIC...does.... SIPC is insurance. The only ones they are being "fair and equitable" to is [sic] the securities industry that pays their salaries.

A relative, Client \#97(B), added:

While our "job" was to get the message out that Madoff was now irrelevant to us, and why SIPC, perverting the laws, was relevant to everyone. If SIPC could do this to us, they could do it to anyone....

The real tragedy was that the SIPC agency created by Congress to protect investors had instead turned against investors in favor of the securities industry it was beholden to....

SIPC has shown that they will not honor their statutory commitments.

In an essay in the same volume, Client \#123 wrote:

But at 9,000 claims, poor old SIPC realized it would be out of money and probably existence if it honored its promises. SIPC's definitions about responsibility were quickly rewritten. Investors who, by SIPC's stated position, had a reasonable expectation to believe securities they were told were purchased on their behalf actually existed, were no longer entitled to have those securities restored to them nor the equivalent value of those securities in cash if the securities were no longer available.... The law firm denying those claims, in the meantime, is billing SIPC close to a million dollars a week, money that's coming right out of the pot to reimburse investors.

Client \#125 had as many suspicions, referring to "the sham of SIPC."

Now the skirmish had escalated into a battle. The trustee, and, in effect, the SIPC were not simply being challenged and harassed by Madoff's victims; they were being taken to court by them. There was the indignity of precisely describing all of the services rendered, of providing "a more detailed synopsis" task by task. The trustee even complained publicly that he and his attorneys had to spend time fighting repeated legal challenges by a handful of victims who "purport to represent a class of those similarly situated." Moreover, the trustee's attorney faced the additional indignity of submitting an affidavit certifying that the application for compensation "complies with guidelines for fee application" under bankruptcy law, and even that in seeking reimbursement for services purchased 
or contracted from a third party it requested money "only for the amount billed."

Less than 2 weeks after the two lawsuits were filed against the trustee, the bankruptcy judge awarded him the fees he had requested. This was the third time the judge had rejected victims' objections in approving legal fees requested by the trustee.

The effects of the actions on the part of Madoff's victims on making the trustee's work less lucrative may have been insignificant; however, they surely made it less pleasant, forcing him to publicly defend himself, his ethics and competence, and entreat the court for his money.

\section{Suing the SEC}

Six weeks after the SEC issued its self critical report, two of the victims of Madoff's Ponzi scheme-a disabled, retired single mother and a physician approaching retirementfiled a lawsuit against the federal government accusing the SEC of negligence for failing to protect investors. The suit asked for monetary damages "arising from the serial, gross negligence ... [during the SEC's] multiple investigations and examinations." Instead, by its implied clean bills of health or seal of approval, the SEC "caused Madoff's scheme to continue, perpetuate, and expand in billions in losses by investors." The two plaintiffs argued that Madoff could have and should have readily been stopped.

The premise of the lawsuit was that the SEC was responsible to Madoff's investors as it is reasonable to expect that they would rely on the SEC to remove risk if it had information that he was engaged in illegal activity. Although it was Madoff's dishonesty that was responsible for their losses, the SEC's actions and inactions, the plaintiffs contended, were a substantial factor in bringing about their injuries. It had not "carried out its functions with even a minimum of reasonable care," and it showed a "wanton" indifference to public safety. The SEC had an obligation to examine and investigate "potential wrongdoing within the context of defined policies and routine common sense practices." However, in spite of multiple complaints and investigations, as well as the several reviews or inquiries, it had failed to do so.

The SEC, the plaintiffs further argued, disregarded its policy that all relevant information from complaints be vetted. This was due to at least one of the following: negligence, incompetence, inexperience, inattentiveness, or laziness. Moreover, it was acknowledged that policies and practices in place for "case opening and closing memoranda, investigation planning memoranda, and communications between SEC offices and teams" were "routinely disregarded." Of particular relevance, in its inquiries the SEC failed not only to confirm Madoff's claimed trading activities, it disregarded pertinent information because of inter-office rivalries, and although it caught Madoff repeatedly in contradictions and inconsistencies, failed to validate or ask him to validate his claims. For example, during the course of one investigation, SEC staff members knew that what he told them about his management of hedge funds and overseas accounts; the reason customer statements were so vague about trading details; and that he did not use e-mail to communicate with clients were all untrue, but they nonetheless continued to rely on his oral representations. He was most obviously lying when he first claimed large scale option trading that was patently nonexistent and later when he reported that he had stopped using such options. These assertions were purported to be central to his claim of why his investment strategy was consistently successful. The SEC did not appear bothered by the barrage of Madoff's untruths, perhaps assuming such behavior was generally expected from the financial organizations it monitored. Or it might have been that some of the time its staff members were simply not paying attention.

The government attorneys responded that the SEC's failure to curtail Madoff's fraud was due to "discretionary judgments" and as a consequence shielded from liability. Quite simply, this means that even if one were to characterize the investigative work of the SEC as incompetent or negligent, the government cannot be sued, unless it agrees to be sued, "based upon the exercise or performance or the failure to exercise or perform a discretionary function or duty." The government's defense was that the law gives it blanket immunity when the judgments of its officials are in question.

\section{A Touch of Greed and Fragile Egos}

As Goffman reminds us, before any con is initiated, one is most likely to find evidence of greed and after any con is executed one is more likely to find a plenitude of bruised egos. With the Madoff Ponzi scheme both greed and bruised egos were much in evidence.

First, in an effort to maximize the annual return on their savings, when pressed on the question, some individuals acknowledged investing a larger percentage of their wealth or too much of it with Madoff than proved to be prudent. More tellingly, some took out an additional mortgage on their home so that they could invest more money in their Madoff account. The contention of victim after victim was that a consistent return of between 8 and 12 percent is what one would expect from any investment, and that they did not find the returns offered by Madoff exceptional. However, if they truly believed this, it is unlikely that any of them would have cashed in all or most of their other investments and borrowed on their homes to increase the 
amount in their Madoff account. Yet: (1) One victim (Client $\# 42 \mathrm{~A}$ ) lost his condominium valued at over $\$ 1$ million because he could no longer afford to make the mortgage, insurance, and maintenance payments. A few years earlier, he had borrowed against it in order to increase the total in his account with Madoff. He blamed his plight on inaction by the government. "Why shouldn't we be fully reimbursed by a government program?" he wondered. "It should be like Social Security and Medicare."

(2) A second victim (Client \#126) was no less inclined to blame the government for her decision to completely trust Madoff: "Upon my retirement, I cashed my pension, 401K, and additional salary that I received. I added all of this to my Madoff IRA." As she too saw it, the government was making the situation a great deal worse: "Only a morally bankrupt society would keep taxes collected as a result of a criminal activity."

(3) A third victim (Client \#147) was simply following what she believed were more knowledgeable relatives: "Slowly in 2003 and the early part of 2004, I liquidated all my holdings from Vanguard and transferred all of it over to Bernie's able hands.... By 2004 I was fully invested with Madoff. I did have a small amount of bonds that I did not add to the pile of monies transferred. In the spring of 2003, I had decided to renovate my small but comfortable Florida condo that was completely paid for; the advice given me by the sage uncle and another financial advisor was to take a 'little extra' out in a loan and move it over to Bernie. 'Don't tie your money up in bricks and stone; have it out there working for you. You'll earn more with Bernie than the bank will charge you in interest.' So, I did just that and started making monthly mortgage payments. I now only owned part of my Florida home, and had also obtained a mortgage to purchase my Pennsylvania home. When it came time for a new car, my advice was not to take a large sum out of my investments with Bernard Madoff, but to get a loan, and make monthly statements. My rate on the bank loan will be less than the money I can earn with Madoff.... When each of my bonds matured, the advice I received was to either live on the money or 'slide it over to Bernard Madoff."

(4) Another victim, who had borrowed to invest with Madoff, asserted that he should be able to write off his bad debt. "Everyone cheats," he complained, "and I'm just not going to be left holding the bag, whatever it takes." (5) Client \#69A detailed her roller coaster ride: "We lived short of our income for 34 years!! Just to be sure everything went into our investments. We did very well with our real estate and sold it all to roll it in to our accounts, then we sold our family home and rolled it in; my husband's pension was rolled in as well as both of our IRAs; I was in a bad car accident and left with many injuries; I rolled my entire settlement into it also. Approximately 7 years ago, our investor decided to stop the annuity investing and other types that he did so we could 'play with the big boys.' He only wanted to make more money for all his retired clients." (6) Like a number of others, Client \#131, a retired businessman, claimed that he was simply following the advice of his accountant: "For many years I had all my investments with Merrill Lynch. I was getting a nice return on my money and was able to retire and live a comfortable life." Apparently this was not enough, as "my accountant suggested I should diversify and recommended me to Madoff, telling me of his great returns on investments.... Eventually, because of his high rate of return I moved all of my money to an IRA account with Madoff."

For many of Madoff's former clients the bruised egos and inevitable sadness were more evident than the greed. This was hardly unexpected. In fact, according to Goffman, the anger of the victims of a con has less to do with greed than with bruised egos. The fact that so few bruised egos had begun to heal a year and a half after Madoff's arrest adds credence to Goffman's conclusion.

The material from the questionnaires and interviews indicates that four other factors often also fostered anger and sadness.

First, the greater the proportion of their wealth individuals lost in the Ponzi scheme, the less likely their anger was to dissipate. With their material life in ruins, those who lost all or most of their money saw their future as bleak. The months and years ahead held little promise and there was little incentive to let go of anger and replace it with new plans or hope. These victims were not eagerly or optimistically looking forward to rebuilding their lives, but were more likely to be still focused on December 11, 2008, venting their anger publicly, hiring attorneys and listening to their advice, and blaming the government for their losses. It is hardly surprising that the greater the reduced circumstances, the greater the anger and sadness. "I'll never get over Madoff," Client \#55 assured me. "He's wrecked my life. There's no money left and no hope. I have nothing. I doubt if I'll ever be happy again." She added that one of her friends, someone who had lived close by, felt the same, and still had many sleepless nights and had become addicted to prescription medicines: "We were sure we were making careful decisions. I just don't know how everything turned out so badly. It's not easy to face each day with any confidence."

Second, the more individuals relied on other victims for information and emotional support, the angrier and sadder they were. To some, this might seem counter intuitive, but an examination of messages shared on the internet, where so many individuals went for information and support, suggests why this occurred. Although much necessary and useful information and good advice were shared on the internet, there was also a surfeit of misinformation and of 
hostile interpretations of what had occurred, was occurring, and would occur, so that a poisonous atmosphere was pervasive. Unsubstantiated assertions were thrown about not only with little regard to their validity, but with little regard to their consequences. Rumors, speculation, and untruths, of course, did little to enhance understanding and dampen the still very raw passions of those in great pain. Too often, exchanges on the internet not only did nothing to cool the mark out, but instead caused a great deal of additional and unnecessary emotional turmoil. "I've heard more than one time," client after client began a sentence before stating some outlandish claim: "The government doesn't want to return our money, it wants to use it to fund a secret research project," or "Madoff could only have done this with help from the highest levels of government."

Third, the more shabbily individuals believed they were treated by the government, the angrier or sadder, or angrier and sadder, they were. This was the case not only for those who actually appeared badly treated, ignored, or given the bureaucratic runaround. And it also included those who believed they were being treated badly because a decision or outcome proved to be unfavorable to their interests. It was relatively easy to convince the Ponzi scheme victims that government officials were not only uncaring, but set against them, determined to harm them even more. In a number of cases auditors for the Internal Revenue Service appeared to be decidedly unhelpful. Some elected officials gave the appearance of carefully listening to the entreaties of victims, but there is little evidence that they followed through with much action. Client \#50's experience is fairly typical: "As for the government, there has been no help whatsoever. I have written many letters to senators and congressmen and women. A very few answered with a standard form letter which really tells me a lot. I'm convinced most don't care one iota. Most didn't even have the decency to reply or acknowledge in any way."

Fourth, the greater the number of other setbacks, for example, health problems, family problems, or other financial problems - in addition to their financial losses due to investing with Madoff-the angrier and sadder they remained. It is obviously more difficult to bounce back from simply losing one's savings in Madoff's Ponzi scheme than from losing one's savings and losing one's spouse to alcoholism or divorce in a very short period of time.

There is no way, of course, to know what the roots of the anger and sadness of Madoff's victims were. All that can be said is that they were very apparent, and were not in the least dissipated by activism-writing letters or essays, broadcasting grievances, suing or the like. In a number of instances, in fact, activism appeared to enhance anger and sadness. Some might conclude that given the facts and the harm caused by Madoff's Ponzi scheme, the levels of anger and sadness were not at all inappropriate, while others might disagree. It is important that while some caught up in Madoff's Ponzi scheme appeared to be angry, angry and sad, or sad; others did not appear to be the least bit emotionally affected, not angry or not sad. It can be said, however, that anger had become an acceptable tenet of their world, very pervasive. As Goffman and any practiced con man surely would have concluded, there would have been less anger, grief, pain, or sadness if there had been someone, some mechanism or institution to cool the marks out.

The sample of quotations from the forty-two files shed light on a great deal more than anger, grief, pain, sadness, or the general state of mind of these Madoff victims a year after he was sentenced to prison, but, more importantly, they shed light on how they were coping with their losses, financial and otherwise, as they waited for justice.

The first point to be made here, however, is that some, almost one in five of the 42 respondents, expressed the belief that although their financial loss was a great personal disappointment that resulted in disrupting their lives significantly, they were reasonably pleased with how their lives had gotten back on track.

Client \#102: "My family and I were very fortunate insofar as we received our original stakes back from SIPC and, also, our capital gains taxes from the IRS. Moreover, we did not, by any means, have all our eggs in one basket (diversification!!!). There was, of course, shock initially and a certain amount of uncertainty until everything was worked out, which took a little more than a year.... The internet and, in particular, a private victims' website, were invaluable in keeping up with developments, getting information, and sorting things out in my own mind.... Finally, I believe that [the trustee's] definition of net equity is absolutely correct, as is his interpretation of SIPA. Thus, I harbor no anger and no grievance against him or anyone else. I blame myself (but only a bit) for being a gullible victim and for not being as smart as [the whistleblower] Harry Markopolos...."

Another victim whose distress was substantially and relatively quickly eased was Client \#131, whose congressional testimony, excerpted in a previous essay, details his losses. "At first," he writes, "the realities of my finances were too much to bear. I was completely wiped out. Absolutely devastated financially; left with no money and few assets. Even after appearing before Congress I had no idea how bad my situation was and how much worse it would get.... To say it was difficult for my wife... and me would be an understatement. We were both in a terrible state of depression, and both undergoing psychological counseling. I have to say there was more than one time I thought about suicide."

However, Client \#131's life turned around fairly rapidly. Friends raised $\$ 50,000$ to help pay the mortgage of his 
home; his son and daughter-in-law gave him $\$ 25,000$; his sister, brother-in-law, sister-in-law, and nephews gave him more money; and his daughter and son-in-law bought him a house. In spite of the fact that his life is clearly materially better, he has not been entirely cooled out. Even after his financial recovery, he was still publicly blaming the SEC for what had occurred: "I could not believe the government would let a thing like this happen."

A second important point is that a considerable amount of grief or pain that the victims had initially felt had dissipated for many, but not for all. Client \#106, who initially "almost killed himself," who "barely made it through each day [because] I was so depressed and frightened," would only go as far as to say that he was "not comfortable" answering questions such as whether the practice of his "old meditation techniques... from having another panic attack" had worked or were working. On the other hand, the outcome for Client \#93, who described the weeks following Madoff's arrest as a period marked by "a terrible depression-I did not drive a car for 3 weeks.... I contemplated suicide often and was put on heavy anti-depression medicine" - was clearly better. After a brief period, he wrote, "I was finally not suicidal and decided to do what I could to try to reinvent my life." Client \#131 admitted that he and his wife "both were in a terrible state of depression, and both undergoing psychological counseling," and added, "I have to say there was more than one time I thought about suicide." However, with the passage of time and with considerable financial help from family and friends, he and his wife "are the two happiest people in the world."

A word of caution: It is important not to exaggerate the victims' greed. They entrusted their money to professional financial advisers, their decisions were supported by family and friends, and government oversight completely failed. It was a perfect storm. Many Americans expect the government to make them whole after a natural disaster. Many Americans expect the government to help them find new employment after they have lost their jobs in an economic downturn. It is hardly surprising that Madoff's victims would expect government help.

The investors most involved in efforts to recover what they had lost, particularly those using the media and the courts to press their case, were in almost every instance those most unwilling to acknowledge that they had been victimized. They were those who most behaved like victims - believing that those who had not shared their fate were not only uncaring and lacked empathy - but had the most difficulty coming to terms with the fact that they had, indeed, been victimized. They needed comfort; they had little need for understanding. They turned to others who also needed comfort. They professed their goodness - their penchant for hard work, their frugality, and their generosity. They were the first to turn on the government and to belittle government officials. They often claimed that those who were making efforts to assist them were not expending enough effort on their behalf. They most likely listened to the advice of attorneys regardless of how questionable it appeared to be. When asked about this assessment, one activist (Client \#146) unhesitatingly shot back: "Sure I'm bitter. You would be too. And I'll continue to be even if every cent is returned. I shouldn't have had to beg for it. It's mine, after all. How would you feel? Someone should have come to me; that would have been fairer." Client \#66, while expressing no bitterness, wondered why "everyone took so much enjoyment in piling on.... Before this happened I would do everything for anyone even before looking at my own needs." And she asked: "I wonder where everybody is today?" Client \#128(C) wrote: "I had felt very depressed for many, many months. It was hard to accept such losses. I felt that I had lost my identity, along with my self-respect. People judge you by what material things you have in your possession, your lifestyle, your money, and that is how they determine your status in the world. I felt crushed and anonymous, as if I had become transparent, and just didn't count anymore." His wife (Client \#124(C)) wrote to the court about her "fear and anxiety," "major depression" daily, and, elsewhere, about how she "thought that suicide was the only answer to stopping the pain."

Although their distrust of others did not appear to be greater than that of victims who were more likely to accept their new circumstances, they were generally more unforgiving. They were clearly among the most rigid of the victims, but there is no way of ascertaining if this was characteristic of them before they had lost their savings to Madoff. A number were very self involved. It would seem their victimization had not only unsettled them financially, but it had badly bruised self images.

\section{Absence of Government Assistance}

Most victims not only did not receive concrete help from the government, but they could not even get government representatives to respond to their questions or appeals. Writing to the court in 2009, Client \#126(C) seemed inconsolable: "It is our money he [Madoff] is using to continue to benefit himself. I am broke-robbed by the Madoff gang." A year later only the focus, not the extent of her anger, had changed: "I spend hours each week on the phone with legislators in an attempt to recover the major source of monies available to me-taxes paid for two decades of fraudulent 1099 income."

\section{Additional Setbacks}

Along with multiplying financial problems, a number of victims report health problems overwhelming them or their 
spouse or both. There is no way, of course, of generally ascertaining how much their being victims of Madoff's Ponzi scheme contributed to acute or chronic health problems, but in some cases a connection seems very obvious.

Client \#23: "Oh that ["your health"] is a big one.... You sure you want to ask?... Well I am at the age of a woman's change and my body was already going through a lot and then with the added stress it went into a tailspin.... I was diagnosed with melanoma 9 months later and 13 months later had a severe reaction to environmental toxins (immune system down) and basically had to live in a bubble for 6 months and try to heal (which I am, yeah....) and then after 15 months [of pain] in my lower back that had me in bed for 2 months.... So now I am 1 month into a fairly healed body and have a whole new appreciation and lust for life.... I realized I was holding so much stress inside of me and emotions that it really almost took me out.... I had always dealt with challenges and life traumas before so I was damned if I was going to be a victim.... I had to be a survivor.... My husband was awesome but he became really sick about 6 months ago due to the stress.... He was just always there for me listening to me cry, listening to my anger [to] help and encourage me to go back to my old job.... He always offered to help with whatever needed to be done but it took its toll."

Client \#50: "My health is very poor and has been going downhill with worry, frustration, and fear as I will pay for my last few months of surgeries, medical expenses, and chemo therapy, which I am about to start. I tell myself, though I'm certainly not ready to do so, that it would be easier if I just died. At least then I could leave something to my two remaining sons, of which we had five.... The last 2 years I have been unable to pay for this [an insurance policy] and I will probably have to give it up, losing all those years of very high premiums, leaving them with nothing but my home, which is modest and which I can no longer afford to keep up as it should be and always was. Is it any wonder my health has declined?"

Client \#69(A): "Our home went into foreclosure. My husband began drinking heavily and we are now in the process of getting divorced.... After losing everything I ended up breaking everything in my ankle and leg while hunting because we need meat for the winter. The following winter my husband fell off a ladder breaking his back while trying to remove large icicles off the edge of our roof because we couldn't afford snow removal any longer for the valleys of our roof. My fibromyalgia and chronic fatigue syndrome increased immensely and now I have developed neuropathy in my hands and feet and have a lot of pain from my bionic ankle. I can't get the medical help I really need due to [the] shortage of money. Some of the drugs I was on are not covered by Medicare and too expensive for me. My ex-husband is quite ill but continues to plow through working."

In answer to the question, "have things turned out better, about the same, or worse...?" she responded: "Worse because of the divorce after 36 years. I'm living on $\$ 2,000$ per month and am disabled. I can't afford the medications I need. If there is any recovery I'm told our portion would be $\$ 80,000$ in $3-5$ years. But we have so many attorneys working on it as a group that I'm sure they'll end up with it all. By then I'll be 70 and probably will have passed on. I can barely afford my little pet.... Both of us didn't have our annual exam this year. We spent it on existing medical bills."

Client \#125(C) writing on behalf of her elderly parents, both children of immigrants, told of their myriad illnesses, including heart disease, diabetes, kidney disease, hip fractures, and hypertension, all made worse "by the stress induced by the loss of all their money." Since Madoff's arrest her father suffered a heart attack and a stroke and her mother is being treated for depression, while both "parents are scared and nervous every single day." The daughter's observation, that because of Madoff her parent's "lives have become circumscribed," is clearly an understatement.

Client \#88: "My life was shattered in 2008, first with the loss of my dear sister and her husband in October. My loyal canine companion ...died. Then on December 11, 2008, I received a call...about my retirement money. I can hardly explain how this affected me, rage, depression, fighting with my husband.... My mental health was at a breakdown, I could not leave the house, I cried constantly. I had to be under a doctor's care. I never felt as violated as I did that day when the call came. Then I was hearing that it would be years before this could be sorted out, hiring a lawyer, costly, useless.... I was completely obsessed with all things Madoff, writing letters, calling people who I thought might be able to assist me. [I spent much time] writing to [the judge], filing my forms with [the trustee], along with filing forms for hardship and SIPC assistance. Each reply I received did not offer up much consolation. Then in February 2009 I felt a lump in my right breast [and] I was diagnosed in March 2009 as Stage 2 then upgraded to Stage 3 breast cancer. Through 2009 I underwent chemo, went bald, felt near death, underwent a right breast mastectomy along with regular and oral radiation from March 2009 until now [late July 2010]. I am still looking at more surgery. My financial situation has been a nightmare.... I lost an investment property at no profit because of the economic climate. ([It] nearly was foreclosed on.) No one in the banking industry wanted to help out with a hardship loan situation. There was no one to help us, we felt abandoned by our government and still do. I have received no help from my government despite folders full of letters to the 
president, senators, congressmen and women.... I would like to have an official e-mail to where my experiences are headed. I failed also to tell you that my husband who is 72 has ESLS (end stage liver disease). I am 63 with breast cancer. We want our money back.... We all suffered and still do suffer under the Madoff fraud." It should be added that some months earlier Client \#88 had written: "The devastation that Bernard Madoff has brought into my life has erased all thoughts of man being inherently good."

The Greeks taught us that when we believe we are better than our fates a bitter ending is inevitable. The Madoff drama had a one-man Greek chorus, Harry Markopolos, warning all who would listen that there was not going to be a happy ending.

\section{Appendix: Nine Victims Speak on TV after Madoff Sentencing} did?"”

"What did you feel when he said, 'I'm sorry for what I

"I didn't believe it."

"I think he's sorry he got caught."

"I didn't believe it when he said he was sorry."

"I didn't believe it, because he has to say he's sorry."

"When he stood up and put his hands behind his back and got handcuffed, I felt about 5 seconds of joy."

"[X], when you heard that he was remanded, that his bail was revoked, did that give you any sense of satisfaction that he would not go back to that penthouse on the Upper East Side and that he was going straight to jail?"

"It's not going to make me any wealthier how he gets punished, but in thinking about the situation, I think that he thinks he's getting away with murder if he's the only one who's gonna go to jail in his family."

"We are in our own jails right now because of his actions."

"So that he's in jail on one hand is, yes, he belongs there, but we need to try to help ourselves get out of our jail now."

"We're just at the very beginning of untangling the legal, financial, and taxation web that he's left behind."

"Can you tell us how your life has changed since December 11th [2008]?"

"December 11th, the same day he turned himself in, we had sent in a check to buy a condo in an active-retirement community, and then the news broke."

"Now we're worrying about having to pay the bills, from never thinking twice about it - if we wanted something, we could get it."

"My family members are in dire straits."

"My aunt and uncle in South Florida are in their 80s."

"They're quite ill."

"They have been turned down for food stamps because their Social Security is too high."
"We no longer spend any discretionary expenses."

"That's gone."

"But the bills keep coming in."

"And now I have to sell-we have to sell-our apartment in this market."

"I have no income coming in."

"I've had to move in with a parent."

"My apartment is up for sale in Florida and, as you know, at 52 years old, to have to move back...."

"You all have told me - or the majority-you believe there is a misconception out there about the Madoff victims. Tell our viewers what that misconception is."

"The perception is that they're just wealthy, greedy people."

"It's not true."

"We've got professional people-doctors, lawyers, bankers - and we also have blue collar workers."

"Plumbers."

"Exactly, those unions."

"And we've got, you know, interior decorators."

"We've got people who are self-employed."

"We've got a lot of teachers, people who just had their life savings."

"Not huge amounts, but it was theirs."

"Is there a lesson here that you'd like to share with anyone?"

"Basically, your question is: What could we have done differently?"

"And you look back, and you say you really can't."

"I looked at the SIPC stamp on the reports."

"My parents had been in it for 20 years."

"I mean, most times when there's a fraud, everybody knows; it comes out fairly quickly."

"The money - the guy disappears; he runs away."

"That wasn't the case here."

"This was long-standing, supposedly a successful firm blessed by the SEC."

"Do you blame [the SEC] most?"

"Absolutely."

"Yes."

"Absolutely."

"This is what they're commissioned to do, and how do [you] expect them to find any fraud if they cannot find the biggest, most blatant fraud that there is?"“If he was sitting where I am right now, what would you say to Mr. Madoff?"

"What happened?"

"How did you think that you were gonna keep doing this, and did you ever stop to think about the ramifications and what you've done to so many thousands of people?"

This exchange fairly accurately captures the thinking of most Madoff victims in the months following his sentencing. Most striking is how decisive they were in apportioning blame 
to others, and how certain they were that nothing they might have done would have prevented them from being harmed so gravely by Madoff. Their attention had quickly turned from themselves, and, in fact, from Madoff, to the government which had abetted him, which made his crime possible. They had granted themselves sufficient moral authority and had positioned themselves to ask that the government take extraordinary steps to make them whole. While their campaign was gaining focus and momentum, the public was growing indifferent, having steadily lost interest in the matter once Madoff was in prison.

Lionel S. Lewis (A.B., Washington University; M.A., Cornell University; Ph.D., Yale University) is professor emeritus of sociology, SUNY/Buffalo. He is the author of 5 books and the author or coauthor of 130 research articles, essays, and reviews, a number published in SOCIETY. This article is the fourth and final one in a planned series on the Madoff Ponzi scheme. 